\title{
Rooting of semihardwood cuttings of olive: indolbutyric acid, calcium and Azospirillum brasilense
}

\author{
Danimar Dalla Rosa', Fabíola Villa', \\ Daniel Fernandes da Silva², Fábio Corbari' \\ 'State University of Western Paraná, Marechal Cândido Rondon,PR, Brazil \\ ${ }^{2}$ Federal University of Lavras, Lavras,MG, Brazi \\ *Corresponding author, e-mail: fvilla2003@libero.it
}

\begin{abstract}
Nowadays the semihardwood cuttings of olive is the most used method to produce seedlings of this specie; however, it is necessary to improve the efficiency of this method to enable the intensive exploitation of this fruit crop and reduce the seedling production costs. Thus, two experiments were conducted concurrently in sand bed, under a canvased shelter of the State University of Western Paraná (Brazil) to evaluate the number and average length of roots per cuttings, the percentage of rooted cuttings, cuttings with callus and dead cuttings. In the first experiment cuttings of olive cultivars Arbequina, Maria da Fé and clone 2 were treated with IBA $\left(3.0 \mathrm{~g} \mathrm{~L}^{-1}\right)$ associated with calcium concentration at $0.0 ; 0.25 ; 0.50$ and $1.0 \mathrm{mmol} \mathrm{L}^{-1}$, implanted in a completely randomized design in a split plot design, with four replications containing ten cutting each, under intermittent mist. For this experiment the Arbequina cultivar presented the highest average number of roots per cutting and the highest percentage of rooted cuttings, but Maria da Fé cultivar promoted the highest average of cuttings with callus. In the second experiment Clone 2 cuttings were submitted to calcium $\left(0.5 \mathrm{mmol} \mathrm{L}^{-1}\right)$ and IBA $\left(3.0 \mathrm{~g} \mathrm{~L}^{-1}\right)$, and substrate inoculation with Azospirillum brasilense bacterium, implanted in a completely randomized design containing three replications of ten cuttings each. In this experiment, the highest percentage of rooted cuttings was obtained for IBA $\left(3.0 \mathrm{~g} \mathrm{~L}^{-1}\right)+\mathrm{A}$. brasilense.
\end{abstract}

Keywords: diazotrophic bacteria, growth regulator, Olea europaea L.

\section{Introduction}

The olive tree has significant importance in the world economy due to its use as oil and fruit by many peoples, especially in the Mediterranean. Nowadays Brazil is the world's third largest olive oil importer and the world's second largest importer of table olives (IOC, 2013).

The Brazilian internal olive shortage may be, among other aspects, result of inadequate climatic conditions and agronomic techniques for implantation and crop management (Oliveira et al., 2010). Among these techniques, the seedling production is an essential factor for activity success. Propagation methods, research and agricultural experiments are crucial for seedling production, planting and formation of new olive orchards (Villa \& Oliveira, 2012).

Among plant propagation methods, asexual reproduction by semihardwood cutting is currently the most used for production of olive seedlings, but rooting rates vary from 0 to $80 \%$, depending on the cultivar used, mainly (Silva et al., 2012). The nutrient availability in both rooting substrate and propagation material is one of the factors that affect the root emission in cuttings. Calcium, for example, affects the formation of new cells and tissues by acting on cell division and formation of the middle lamella, in the process of root growth and for being constituent of the plant cell wall (Marschner, 2012). 
Plant growth regulators, such as auxins, have been also commonly used and considered essential for rooting cuttings, and auxin is considered essential for rooting semihardwood olive cuttings (Oliveira et al., 2009). Microorganisms such as arbuscular mycorrhizal fungi and diazotrophic bacteria have also been studied, since they influence the development of adventitious roots and aerial plant shoots, either by seed and cutting inoculation, or by their incorporation into the rooting substrate (Vogel et al., 2014; Melo et al., 2012).

Among diazotrophic bacteria one of the most important and known species is Azospririllum brasilense for its production capacity of indole-acetic acid (AIA) auxin. The effects of rhizobacteria inoculation with genus Azospirillum spp. are especially related to root growth or morphology, increasing the number of lateral and thin roots, and leading to root surface enlargement, which results in better nutrient and water absorption, may be the main factor of plant growth (Bottini et al., 2004).

The need to improve the cutting rooting efficiency is fundamental to enhance the revenues of seedling production process in nurseries (Vieira Neto et al., 2011). In this sense, the objective of this work was to evaluate the use of auxin, calcium and Azospririllum brasilense on rooting of semihardwood olive cuttings.

\section{Material and Methods}

Two experiments were carried out in May 2013 simultaneously, and installed in the nursery of seedlings of the "Professor Mário César Lopes" Horticulture and Protected Cultivation Experimental Station. The station is located at the geographical coordinates $54^{\circ} 22^{\prime} \mathrm{W}, 24^{\circ} 46^{\prime} \mathrm{S}$ and altitude of 420 meters above sea level, and it belongs to the Experimental Station Nucleus of the Universidade Estadual do Oeste do Paraná (Unioeste), Campus Marechal Cândido Rondon, Paraná State, Brazil.

The region climate according to the Köppen classification is cfa type, subtropical (Caviglione et al., 2000) with annual average precipitation between 1600-1800 mm and air humidity between $70-75 \%$. The annual average air temperature range from 22 to $23^{\circ} \mathrm{C}$ (IAPAR,
2010).

The experiments were installed in a canvased shelter with $50 \%$ solar radiation retention, also closed on all sides, and in a masonry bed filled with washed sand of medium granulometry. At thirty days before the experiments the substrate was disinfected using sodium hypochlorite $(4 \mathrm{~mL}$ of chlorine per $\mathrm{m}^{2}$ ). Then the seed bed was covered with clear plastic to avoid sand contamination until the cutting treatment.

A low tunnel was built on the sand bed using iron rods 4 meters long and $1 / 4$ inch in diameter covered with 200 micron clear canvas. A nebulization system was installed with intermittent activation from 7:00 am to 6:00 p.m., based on average temperature and air humidity throughout the day, in order to maintain high air humidity and, thus, provide favorable conditions for rooting olive cuttings.

Inside the tunnel environmental conditions were monitored with a Data logger installed inside a meteorological shelter and performing hourly measurements of relative air humidity and air temperature during the entire period of the experiment (data recorded in Figure 1).

The percentage of sand moisture contained in the sand bed was also measured in four random samples collected at $10 \mathrm{~cm}$ deep, and then oven dried. This percentage was then estimated by the arithmetic mean of the differences between the dry and wet mass of each sample, and obtaining an average of $6.0 \%$ moisture.

The number of roots/cutting (NRC), percentage of rooted cuttings (\%R), cuttings with callus $(\% \mathrm{C})$, dead cuttings (\%D) and average root length/cutting (ARLC) were evaluated considering all cuttings of each repetition for validation of rooted and dead cuttings and cuttings with callus, beyond root length in five roots in each cutting.

\section{Experiment 1}

It consisted in rooting three olive genotypes, Arbequina and Maria da Fé beyond Clone 2, submitted to cutting treatment with four rooting solutions, being $3 \mathrm{~g} \mathrm{~L}^{-1}$ of IBA and IBA 


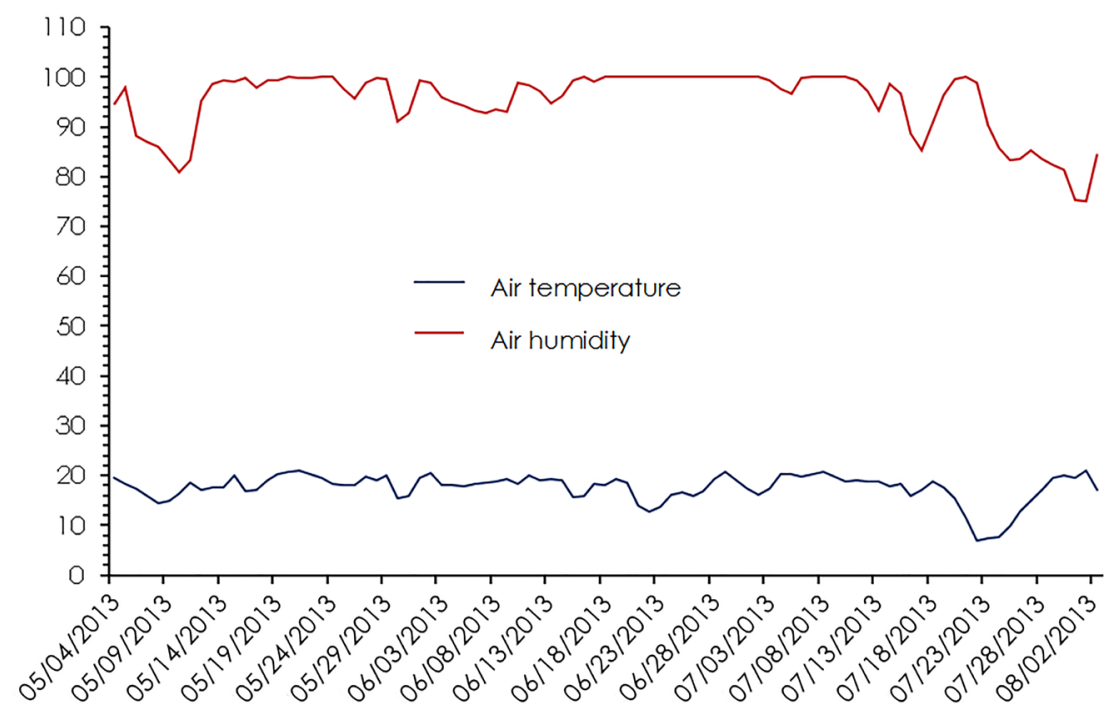

Figure 1. Air temperature $\left({ }^{\circ} \mathrm{C}\right)$ and air humidity measured during the execution of the experiment. Unioeste, Marechal Cândido Rondon, Brazil. 2014.

solution associated with solutions of calcium $(0.25$ $\mathrm{mmol} \mathrm{L-1}, 0.5 \mathrm{mmol}^{-1}$ and $\left.1.0 \mathrm{mmol}^{-1}\right)$.

To prepare the IBA solution, $3.0 \mathrm{~g}$ of indolebutyric acid (IBA) was diluted in $250 \mathrm{~mL}$ of ethyl alcohol at $92.5 \%$ contained in a $500 \mathrm{~mL}$ volumetric flask. After the complete dilution, the volume of the flask was filled with distilled water. For the preparation of the calcium solutions, $14.701 \mathrm{~g}$ of calcium chloride dihydrate $\left(\mathrm{CaCl}_{2} \cdot 2 \mathrm{H}_{2} \mathrm{O}\right.$, molar mass: $\left.147.01 \mathrm{~g} \mathrm{~mol}^{-1}\right)$, diluted in $100 \mathrm{~mL}$ of distilled water, were weighed in analytical balance, obtaining thus a solution of calcium with $1.00 \mathrm{~mol} \mathrm{~L}^{-1}$. Subsequently this solution was diluted, obtaining concentrations of $0.50 \mathrm{mmol} \mathrm{L}^{-1} ; 1.00 \mathrm{mmol} \mathrm{L}^{-1}$ and $2.00 \mathrm{mmol}^{-1}$. Then, these solutions were mixed $(50 \%$ of each, $\mathrm{v} / \mathrm{v}$ ) with the IBA solution, obtaining the solutions used for the treatment of the cuttings.

After branch collection, the cuttings were made, with length ranging from 12 and $15 \mathrm{~cm}$ and $4 \mathrm{~mm}$ in diameter, leaving 2 pairs of leaves only in the upper part. Immediately after their preparation, the cuttings were treated with IBA and calcium, immersing about $5 \mathrm{~cm}$ of its base for 10 seconds in each solution, and then immediately taken to the sand bed, arranged in spacing $5 \times 5 \mathrm{~cm}$ and $5 \mathrm{~cm}$ depth.

The experimental design was completely randomized, in a subdivided plots, with parcels composed by the rooting solutions and the subplot composed by the olive cultivars, containing four replications of ten cuttings per replicate, totaling 480 cuttings.

For this experiment, the data obtained were submitted to analysis of variance and corrected for $(Y+0.5)^{\wedge} 0.5$. Subsequently, the Tukey test was applied to compare means at $5 \%$ significance. All analyzes were performed using the SISVAR statistical program (Ferreira, 2011).

\section{Experiment 2}

It was constituted in cutting rooting of clone 2 olive cultivar (local cultivar under identification process) submitted to eight treatments (control; $3 \mathrm{~g} \mathrm{~L}^{-1}$ de IBA; $05 \mathrm{mmol} \mathrm{L}^{-1}$ de calcium; A. brasilense, strains Ab-V5 + Ab-V6; 3 $\mathrm{g} \mathrm{L}^{-1}$ de IBA + $0.5 \mathrm{mmol} \mathrm{L^{-1 }}$ de calcium; $3 \mathrm{~g} \mathrm{~L}^{-1}$ de $\mathrm{IBA}+$ Azospirillum brasilense, strains Ab-V5 + AbV6; $0.5 \mathrm{mmol} \mathrm{L}^{-1}$ de calcium + A. brasilense, strains $\mathrm{Ab}-\mathrm{V} 5+\mathrm{Ab}-\mathrm{V} 6 ; 3 \mathrm{~g} \mathrm{~L}^{-1}$ de IBA $+0.5 \mathrm{mmol} \mathrm{L}^{-1} \mathrm{de}$ calcium + A. brasilense, strains Ab-V5 + Ab-V6).

For the preparation of the $3 \mathrm{~g} \mathrm{~L}^{-1}$ solutions of IBA; $0.5 \mathrm{mmol} \mathrm{L}^{-1}$ of calcium and $3 \mathrm{~g} \mathrm{~L}^{-1}$ of IBA +0.5 $\mathrm{mmol} \mathrm{L}^{-1}$ of calcium, as well as for the preparation of the cuttings and solutions application, the same procedures and techniques previously described for Experiment 1 were performed.

For the preparation of the treatments containing Azospirillum brasilense $120 \mathrm{ml}$ of the commercial product Azototal ${ }^{\otimes}$ (Azospirillum brasilense strains Ab-V5 + Ab-V6) was used. Distilled water was added to the commercial product until reaching the $4 \mathrm{~L}$ volume, thus conferring a concentration of $30 \mathrm{~mL} \mathrm{~L}^{-1}$ of 
Azotota $^{\oplus}$, being later applied with the aid of a watering can on the cuttings distributed in the sand bed. In a theoretical estimation the application of $\mathrm{A}$. brasilense was equivalent to $187.5 \mathrm{~mL}$ of the commercial product per $\mathrm{m}^{2}$ of sand bed. In the conditions adopted for the experiment, this is equivalent to $1 \times 10^{8}$ cells of $A$. brasilense/cutting.

The experimental design was completely randomized, containing eight treatments and three replicates of 10 cuttings each, totaling 240 cuttings. After the data collection, the data were submitted to analysis of variance and corrected for $(Y+1.0) \wedge 0.5$. Subsequently, the Tukey test was applied for mean comparison, with a $5 \%$ probability of error. All analyzes were performed using the statistical program Sisvar (Ferreira, 2011).

\section{Results and Discussion}

\section{Experiment 1}

According to the analysis of variance it was observed a significant interaction between rooting solutions and olive cultivars only for the average number of roots per cutting. For Arbequina cultivar, the average number of roots/cutting was higher when the cuttings were treated with IBA $+1.0 \mathrm{mmol} \mathrm{L}^{-1}$ of calcium, when compared to the solution of IBA and IBA +0.5 mmol L-1 of calcium (Table 1).

An analysis of Table 1 data shows that olive cultivars behaved differently with in relation to the number of roots/cutting when treated with different calcium concentrations. In this case, Arbequina cultivar detached and its rhizogenic potential was higher than the other cultivars, a fact also highlighted in other research works performed by Silva et al. (2012).

Whether considered the plant nutrition aspects on adventitious roots formation, Cunha et al. (2009) reported that innumerable nutrients are involved in the metabolic processes associated with root formation in cuttings. In addition, calcium and iron, copper, boron, manganese and zinc are linked to the growth and development of the root system, since they participate in cell wall formation, lignification and plant cell elongation. Calcium supports the formation of new plant cells and tissues because it is a secondary messenger and it is involved in the transduction processes, whereas boron is directly linked to the processes of differentiation and cell division, and these elements may be associated with the root formation in cuttings ( Façanha et al., 2008).

Although there are innumerous claims regarding increases in plant rhizogenesis due to nutrient use, Palú et al. (2013) verified no influence of biofertilizer based on calcium and other nutrients, on rooting of passion fruit cuttings. Additionally, Cunha et al. (2009) concluded that the plant nutrition effect on adventitious rhizogenesis is not yet fully understood due to the rhizogenic process complexity and the innumerable interactions between mineral nutrients.

The scarcity of studies on the relationship between plant nutrition and rhizogenesis phases in cuttings suggests that new research should be carried out in order to identify the role of each nutrient on rhizogenic process, especially for olive.

For percentage of rooted and dead cuttings, cuttings with callus, and root length and number of roots/cutting, significance was recorded for live cultivars only. Regarding the average number of roots/cutting, Arbequina cultivar presented higher values (Table 2). These results corroborate with Silva et al. (2012) who include this cultivar in the group with the highest average number of roots/cutting.

Table 1. Number of roots/cutting as a function of olive cultivars and rooting solutions. Unioeste, Marechal Cândido Rondon, 2014.

\begin{tabular}{|c|c|c|c|c|c|c|}
\hline \multirow{3}{*}{$\begin{array}{l}\text { Rooting solutions } \\
\text { IBA }\end{array}$} & \multicolumn{6}{|c|}{ Olive cultivars } \\
\hline & \multicolumn{2}{|c|}{ Arbequina } & \multicolumn{2}{|c|}{ Clone 2} & \multicolumn{2}{|c|}{ Maria da Fé } \\
\hline & $(5.19) 2.21^{* *}$ & $A b^{*}$ & $(4.04) 2.11$ & $\mathrm{Aa}$ & (3.22) 1.80 & $\mathrm{Aa}$ \\
\hline $\mathrm{IBA}+0.25 \mathrm{mmol} \mathrm{L}^{-1}$ of calcium & (9.04) 3.04 & Aab & (3.04) 1.88 & $\mathrm{Aa}$ & (5.51) 2.43 & Aa \\
\hline $\mathrm{IBA}+0.50 \mathrm{mmol} \mathrm{L}^{-1}$ of calcium & (3.87) 1.89 & $\mathrm{Ab}$ & (4.67) 2.25 & $\mathrm{Aa}$ & $(5.96) 2.51$ & $\mathrm{Aa}$ \\
\hline $\mathrm{IBA}+1.00 \mathrm{mmol} \mathrm{L}^{-1}$ of calcium & (14.12) 3.75 & $\mathrm{Aa}$ & $(4.25) 2.13$ & $\mathrm{Ba}$ & $(2.96) 1.73$ & $\mathrm{Ba}$ \\
\hline
\end{tabular}


The rhizogenic potential of Arbequina cultivar was also detached by Vieira Neto et al. (2005), who obtained an average of 6.3 roots/ cutting, highlighting the superiority of this cultivar for this characteristic, although, the rooting is influenced by several factors and not only by the genetic potential (Fachinello et al., 2005 ). In relation to the percentage of rooted cuttings, the Maria da Fé cultivar showed higher values than Arbequina cultivar (Table 2).

Table 2. Number of roots/cutting (NRC), percentage of rooted cuttings (\%R), cuttings with callus (\%C), dead cuttings (\%D) and average root length/cutting (ARLC) as a function of olive cultivars and rooting solutions. Unioeste, Marechal Cândido Rondon, 2014.

\begin{tabular}{|c|c|c|c|c|c|}
\hline \multirow{3}{*}{ Olive cultivars } & \multicolumn{5}{|c|}{ Variables studied } \\
\hline & \multirow{2}{*}{ NRC } & $\% R$ & $\% \mathrm{C}$ & $\% \mathrm{D}$ & ARLC \\
\hline & & - & - & ---------------- & $\mathrm{mm}$ \\
\hline Arbequina & $(8.06)$ 2.72a* & (16.25) 3.84b & $(08.75) 2.31 b$ & $(75.00) 8.63 a$ & (15.97) 3.70b \\
\hline Clone 2 & $(4.00) 2.09 b$ & (30.00) 5.39ab & (16.25) 3.37b & (53.75) $7.30 a$ & (34.57) 5.72a \\
\hline Maria da Fé & $(4.41) 2.12 \mathrm{~b}$ & $(37.50) 5.70 a$ & $(36.87) 5.90 a$ & (24.37) 4.57b & $(39.61) 5.91 \mathrm{a}$ \\
\hline CV \% & 28.49 & 37.87 & 55.81 & 23.41 & 38.77 \\
\hline MSD & 0.57 & 1.63 & 1.87 & 1.39 & 1.72 \\
\hline
\end{tabular}

This contradiction may be related to the collection of cuttings, as described by Oliveira et al. (2009), when they obtained difference of more than $15 \%$ for cuttings with roots for the same cultivar when collected in April and July. Another factor that may have led to the discrepancy of the results was the substrate used, as demonstrated Oliveira et al. (2012) that obtained variation up to $98 \%$ for cutting with roots when compared sand with perlite.

In relation to the percentage cuttings with callus and percentage of dead cuttings, the cultivar Maria da Fé presented, respectively, the highest and lowest value (Table 2). This result means that Maria da Fé cultivar had good experimental conditions for rooting, since the callus formation on basal part of olive cuttings refers to the meristematic cells division, and this effect is closely related to rooting (Peixe et al., 2007), and the cutting death means non-viability of the propagating material. The high number of cuttings with callus of Maria da Fé cultivar was also observed by Oliveira et al. (2012) who also verified a higher percentage of rooting for this cultivar.
Clone 2 and Maria da Fé olive cultivars presented the highest average root length. This result is not as desirable as other characteristics, such as the average number of roots per cutting or the percentage of cuttings with roots, which, according to Peixe et al. (2007) are primordial for the adventitious root formation in cuttings because, in the seedling production process, when the cuttings are transferred to plastic tubes or bags, the root system may appear larger than the container that will receive the rooted cutting, making root pruning necessary to prevent root folding. However, this process requires a greater labor, and may cause greater root vulnerability to the pathogen attack.

\section{Experiment 2}

The analysis of variance showed significant differences among the treatments analyzed only for percentage of rooted cuttings, and the cuttings that received the treatments with IBA + Azospirillum were statistically superior to the control and treatment with calcium + Azospirillum braziliense (Table 3).

This superiority is related to the ability of 
this group of bacteria to produce indolacetic acid (AIA) (Baudoin et al., 2010), the most abundant natural auxin (plant hormone) present in plants and responsible for cell differentiation and adventitious root emission (Dartora et al., 2013, Mercier, 2008); making possible to affirm that there was a synergic effect between bacteria and IBA for the percentage of rooted cuttings.

Spaepen et al. (2007) corroborate with this statement and argue that the benefits provided by diazotrophic bacteria are linked to the plant hormones production, such as auxins, gibberellins and cytokinins that are able to stimulate plant growth, especially roots. Indeed, the AIA produced by Azospirillum brasilense and other diazotrophic bacteria species allows rooting of semihardwood olive cuttings similar to that promoted by plant regulators with the possibility of replacing these substances by the inoculation of these bacteria groups.

The positive results recorded for diazotrophic bacteria on rooting hardwood cuttings were also observed by Melo et al. (2012) that reportred rooting rate increase for eucalyptus cuttings by incorporating Herbaspirillum seropedicae, ZAE94 strains to the substrate. Thus, it can be stated that diazotrophic bacteria used alone or associated with plant regulators can maximize the rhizogenic potential of cuttings, increasing efficiency and reducing costs for seedling production.

However, more detailed studies are necessary to reveal the effects of these microorganisms adventitious root formation process, especially for olive cuttings. Such studies may focus on bacteria inoculation directly at the cutting base to be rooted, or even its use after the transplanting in field, seeking to improve the fruit yield of olive orchards.

Table 3. Percentage of rooted cuttings (\%R), cuttings with callus (\%C), dead cuttings (\%D), average root length/ cutting (ARLC) and number of roots/cutting (NRC) as a function of tested treatments. Unioeste, Marechal Cândido Rondon, 2014.

\begin{tabular}{|c|c|c|c|c|c|}
\hline \multirow[b]{2}{*}{ Treatments } & \multicolumn{5}{|c|}{ Variables studied } \\
\hline & $\% R$ & \%C & $\% D$ & $\begin{array}{c}\text { ARLC } \\
---m m--\end{array}$ & NRC \\
\hline Non-treated & (0.00) 1.00b & $(6.61) 2.19 a$ & (93.33) 9.70a & $(0.00) 1.00 a$ & $(0.00) 1.00 a$ \\
\hline IBA & (6.67) $2.19 \mathrm{ab}$ & $(20.00) 3.82 a$ & (73.33) 8.39a & $(11.06) 2.62 a$ & (1.33) $1.41 \mathrm{a}$ \\
\hline Calcium & (3.33) 1.77ab & $(10.00) 2.52 a$ & (86.67) 9.34a & $(11.62) 2.66 a$ & $(0.33) 1.14 a$ \\
\hline A. brasilense & (6.67) 2.54ab & $(0.00) 1.00 a$ & (93.33) $9.71 \mathrm{a}$ & $(32.91) 4.91 \mathrm{a}$ & $(1.00) 1.38 a$ \\
\hline $\mathrm{IBA}+$ calcium & (6.67) $2.19 a b$ & $(0.00) 1.00 a$ & $(90.00) 9.51 a$ & $(3.11) 1.74 a$ & $(1.50) 1.45 a$ \\
\hline IBA + A. brasilense & $(30.00) 5.52 a$ & $(10.00) 2.53 a$ & $(60.00) 7.74 a$ & $(37.02) 6.12 a$ & (3.69) $2.15 a$ \\
\hline Calcium + A. brasilense & $(0.00) 1.00 \mathrm{~b}$ & $(0.00) 1.00 a$ & $(100.00) 10.05 a$ & $(0.00) 1.00 a$ & $(0.00) 1.00 a$ \\
\hline IBA + calcium + A. brasilense & (13.33) 3.39ab & (23.33) 4.77a & $(63.33) 8.02 a$ & $(16.83) 3.72 a$ & $(1.66) 1.55 a$ \\
\hline $\mathrm{CV}(\%)$ & 59.89 & 82.58 & 12.26 & 74.53 & 34.16 \\
\hline MSD & 4.15 & 5.5 & 3.14 & 6.26 & 1.34 \\
\hline
\end{tabular}

\section{Conclusions}

The application of $1.00 \mathrm{mmol} \mathrm{L}^{-1}$ of calcium increases the number of roots per cutting of Arbequina olive cultivar;

The higher average number of roots and lower average length of roots is verified in Arbequina olive cultivar;

The Maria da Fé cultivar presents a higher percentage of rooted cuttings and cuttings with callous than Arbequina cultivar;

The use of Azospirillum brasilense associated with IBA increased the percentage of clone 2 rooted cuttings.

\section{References}

Baudoin, E., Lerner, A., Mirza, M.S., Zemrany, H., Combaret, C.P., Jurkevich, E., Spaepen, S., Vanderleyden, J., Nazaret, S., Okon, Y., Loccoz, Y.M. 2010. Effects of Azospirillum brasilense with genetically modified auxin biosynthesis gene ipdC upon the diversity of the indigenous microbiota of the wheat rhizosphere. Research in Microbiology 161: 219-226.

Bottini, R., Cassán, F., Piccoli, P. 2004. Gibberellin production by bacteria and its involvement in plant growth promotion and yield increase. Applied Microbiology and Biotechnology 65: 497-503. 
Caviglione, J. H., Kiihl, L.R.B., Caramori, P.H.; Oliveira, D. 2000. Cartas climáticas do Paraná. IAPAR, Londrina, Brazil. (CD-ROM).

Cunha, A.C.M.C.M., Paiva, H.N., Xavier, A., Otoni, W.C. 2009. Papel da nutrição mineral na formação de raízes adventícias em plantas lenhosas. Pesquisa Florestal Brasileira, 58: 35-47.

Dartora, J., Guimarães, V.F., Marini, D., Sander, G. 2013. Adubação nitrogenada associada à inoculação com Azospirillum brasilense e Herbaspirillum seropedicae na cultura do milho. Revista Brasileira de Engenharia Agrícola e Ambiental 17: 1023-1029.

Façanha, A.R., Canellas, L.P., Bobbss, L.B. 2008. Nutrição mineral In: Kerbauy, G.B. (ed.) Fisiologia vegetal. Guanabara Koogan, Rio de Janeiro, Brazil. p. 33-81.

Fachinello, J.C., Hoffmann, A., Nachtigal, J.C. 2005. Propagação de plantas frutíferas de clima temperado. UFPel, Pelotas, Brazil. 178p.

Ferreira, D.F. 2011 . SISVAR: a computer statistical analysis system. Ciência \& Agrotecnologia 35: 1039-1042.

IAPAR. Instituto Agronômico do Paraná. Estações meteorológicas. Bolem técnico Londrina, 2010.

IOC. World table olive figures. 2013. http://www. internationaloliveoil.org/estaticos/view/132world-table-olive-figures <Acesso em 9 mar. 2014>.

Marschner, H. 2012. Mineral nutrition of higher plants. Academic Press, London, UK. 889 p.

Melo, L.C., Oliveira, C.V., Manfredi, C., Baldani, V.L.D., Ferreira, J.S. 2012. Efeito de bactérias na promoção do enraizamento em clone de eucalipto. Enciclopédia Biosfera 8: 736-748.

Mercier, H. 2008. Auxinas. In: Kerbauy, G.B. (ed.) Fisiologia vegetal. Guanabara Koogan, Rio de Janeiro, Brazil. p. 182-211.

Oliveira, A.F., Chalfun, N.N.J., Alvarenga, A.A., Vieira Neto, J., Pio, R., Oliveira, D. L. 2009. Estaquia de oliveira em diferentes épocas, substratos e doses de AIB diluído em $\mathrm{NaOH}$ e álcool. Ciência \& Agrotecnologia 33: 79-85.

Oliveira, A.F., Vieira Neto, J., Villa, F., Silva, A.F.O. 2010. Desempenho de jardins clonais de oliveira obtidos por estaquia e enxertia em cortes sucessivos. Scientia Agraria 1: 299-305.

Oliveira, M.C., Ramos, J.D., Pio, R., Santos, V.A., Silva, F.O.R. 2012. Enraizamento de estacas em cultivares de oliveiras promissores para a Serra da Mantiqueira. Ceres 59: 147-150.
Palú, E.G., Krause, W., Batisitti, M., Santos, P.R.J., Netto, M.A. 2013. Doses de fertilizante mineral misto e diferentes recipientes no enraizamento de estacas de maracujazeiro amarelo. Enciclopédia biosfera 9: 736-748.

Peixe, A., Serras, M., Zavattieri, A.M., Dias, S.A.M. 2007. Estudo histológico sobre a formação de raízes adventícias em estacas caulinares de oliveira (Olea europaea L.). Revista de Ciências Agrárias 30: 476-482.

Spaepen, S., Versées, W., Gocke, D., Pohl, M., Steyaert, J., Vanderleyden, J. 2007. Characterization of phenylpyruvate decarboxylase, involved in auxin production of Azospirillum brasilense. Journal of Bacteriology 189: 7626-7633.

Silva, L.F.O., Oliveira, A.F., Pio, R., Zambon, C.R., Oliveira, D.L. 2012. Enraizamento de estacas semilenhosas de cultivares de oliveira. Bragantia 71: 488-492.

Vieira Neto, J., Oliveira, A.F., Caproni, C.M., Villa, F. 2011 . Desempenho de jardins clonais de oliveira (Olea europaea) em cortes sucessivos visando a sua propagação por estaquia. Cerne 17: 117-122.

Villa, F., Oliveira, A.F. 2012. Origem e expansão da oliveira na América Latina. In: Oliveira, A.F. (ed.) Oliveira no Brasil tecnologias de produção. EPAMIG, Belo Horizonte, Brazil. p. 21-38.

Vogel, G., Martinkoski, L., Ruzicki, M. 2014. Efeitos da utilização de Azospirillum brasilense em poáceas forrageiras: importâncias e resultados. Agropecuária Científica no Semi-Árido 10: 1-6. 